\title{
Salinity and freshwater discharge determine rotifer distribution at the Mossoró River Estuary (Semiarid Region of Brazil)
}

\author{
Medeiros, AMA. ${ }^{\mathrm{a} *}$, Barbosa, JEL. ${ }^{\mathrm{b}}$, Medeiros, $P R{ }^{\mathrm{a}}$, Rocha, $R M .^{\mathrm{c}}$ and Silva, $L F^{\mathrm{c}}$

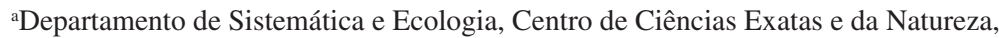 \\ Universidade Federal da Paraíba - UFPB, Cidade Universitária, Campus I, CEP 58059-900, João Pessoa, PB, Brazil \\ bDepartamento de Biologia, Universidade Estadual da Paraíba - UEPB, \\ Av. das Bananeiras, 351, CEP 58109-753, Campina Grande, PB, Brazil \\ 'Laboratório de Ecologia do Semi-Árido - LABESA, Universidade Federal do Rio Grande do Norte - UFRN, \\ R. José Evaristo, CEP 59300-000, Caicó, RN, Brazil \\ *e-mail: ana.maria.bio@gmail.com \\ Received April 27, 2009 - Accepted September 25, 2009 - Distributed August 31, 2010
}

(With 3 figures)

\begin{abstract}
The present study aimed at evaluating differences in rotifer distribution in three estuarine zones in an inverse estuary located in the Semiarid Region of Brazil. Zones were chosen based on their proximity to the ocean and river border as a means of reflecting a horizontal salinity gradient. High freshwater discharge during the rainy season was the major determinant of rotifer composition. On the other hand, due to higher salinity values during the dry season, very low values of species richness and abundance were observed in all zones. Therefore, the study highlights the constraints of salinity and the positive influence of seasonality and river proximity on rotifer species in a semiarid estuarine environment.
\end{abstract}

Keywords: rotifera, zooplankton, salinity, tropical inverse estuary, Semiarid Brazil.

\section{Salinidade e descarga de água doce determinam a distribuição de rotíferos no estuário do Rio Mossoró (região semiárida do Brasil)}

\begin{abstract}
Resumo
O presente estudo objetivou avaliar diferenças na distribuição de rotíferos em três zonas estuarinas em um estuário inverso localizado na região semiárida do Brasil. As zonas foram escolhidas com base em suas proximidades com o oceano e a margem do rio de forma a representar um gradiente de salinidade horizontal. A forte entrada de água doce durante o período chuvoso foi o maior determinante da composição de rotíferos. Do outro lado, devido aos maiores valores de salinidade durante o período seco, valores muito baixos de riqueza de espécies e abundância foram observados em todas as zonas. Dessa forma, o estudo demonstra as restrições da salinidade e a influência positiva da sazonalidade e da proximidade com o rio sobre as espécies de rotíferos em um ambiente estuarino do semiárido.
\end{abstract}

Palavras-chave: rotífera, zooplâncton, salinidade, estuário inverso tropical, semiárido do Brasil.

\section{Introduction}

Of the approximately 1,800 Rotifera species described, only a few are able to tolerate brackish and saline waters (Miracle and Serra, 1989; Onwudinjo and Egborge, 1994; Fontaneto et al., 2006, Zakaria et al., 2007). Therefore, compared to saline and brackish environments, freshwater environments generally sustain considerably larger quantities of rotifer species (Remane, 1971; Fontaneto et al., 2006). Due to the prominent physiological constraints of saltwater on most rotifers, this group is of particular interest to test for ecological responses with regards to salinity variations on both spatial and seasonal scales on estuarine systems.
Evaluating relationships between zooplankton species and salinity have been central goals for many community ecologists worldwide (e.g. Miracle and Serra, 1989; Hammer, 1993; Lansac-Tôha and Lima, 1993; Keller and Conlin, 1994; Onwudinjo and Egborge, 1994; Williams, 1998; Epifanio and Garvine, 2001; Herbst, 2001; Ara, 2002; Derry et al., 2003; Toumi et al., 2005; Fontaneto et al., 2006; Zakaria et al., 2007). However, despite these previously accomplished studies, new questions frequently arise and contrasting results suggest that the influence of environmental factors on species composition 
is site-dependent. Thus, rotifer distribution may be different than generally expected when environmental particularities are taken into account.

Many studies on the zooplankton distribution of estuaries have detected that zooplankton richness and abundance tend to increase upstream (e.g. Medeiros, 1983; Neumann-Leitão, 1994; Magalhães et al., 2006; Silva et al., 2009). These authors attributed these findings to opposing patterns of salt concentration and zooplankton distribution, with freshwater being a highly important determinant.

The Mossoró River Estuary is under strong semiarid climatic influences, showing an inverse salinity gradient in which salt concentration is higher with proximity to the river. In the present study we evaluated patterns of rotifer distribution spatially and seasonally, and the processes responsible for these patterns. We tested the hypothesis that salinity and rainfall have, respectively, negative and positive effects on rotifer distribution. The study was carried out in a tropical inverse estuary of Brazil, and also aims at contributing to the knowledge of the poorly-studied semiarid zooplankton ecology (but see Shiel et al., 2006).

\section{Material and Methods}

\subsection{Study area}

The Mossoró River Estuary is located in Rio Grande do Norte State, in the Northeastern, Semi-arid Region of Brazil (Figure 1). The estuary extends from the lower portion, connected to the Atlantic Ocean, to about $24 \mathrm{~km}$ upstream, near the river border, yet still under tidal influences. The estuary has an average depth of $6 \mathrm{~m}$ and typically receives low, concentrated, annual rainfall between February and June. It is particularly unique for its inverse salinity gradient in which salt concentration increases upstream. As a consequence of a negative 'freshwater input' 'evaporation' ratio, the estuary sustains salinity levels varying between brackish on the lower reach (salinity: $\sim 10$ g. $\mathrm{L}^{-1}$ ) and saline at the upper reach $\left(\sim 30\right.$ g. $\left.\mathrm{L}^{-1}\right)$. Occasionally, even hypersaline levels (> 50 g.L $\mathrm{L}^{-1}$; see Hammer, 1986) can be observed at the upper reach of the estuary (Silva et al., 2009). Due to these features, the area is highly explored by the salt extracting industry with an annual salt production of approximately 2,400,000 t.

\subsection{Sampling design}

Monthly sampling was carried out over one year in three zones, between October of 2006 and September of 2007. Zones were chosen based on their proximity to the ocean or the river border, as follows: lower zone 'LZ' (near the ocean), middle zone 'MZ' (between the ocean and the river border) and the upper zone 'UZ' (near the river border) (Figure 1). In each zone, environmental variables and zooplankton were sampled monthly at two permanent sites, always during the day, and at high tide.

Environmental variables evaluated were (material description): salinity (Fisher portable refractometer), water temperature (digital thermometer with $0.1^{\circ} \mathrm{C}$ accuracy), $\mathrm{pH}$ (Hanna portable membrane $\mathrm{pHmeter}$ ) and water transparency
(Secchi disk). Also, water samples were collected for analysis of dissolved oxygen and later evaluated in the laboratory following Winkler`s procedures. Additional water samples were collected in PVC bottles previously cleaned with deionized water and stored in recipients containing ice for transportation to the lab, where they were frozen and nutrients (ammonia: $\mathrm{NH}_{3}$, nitrite: $\mathrm{NO}_{2}$, nitrate: $\mathrm{NO}_{3}$ and total phosphorus TP) were examined according to the procedures described by Rodier (1975), Mackereth et al. (1978) and APHA (1995). Chlorophyll and pheophytin concentrations were determined spectrophotometrically based on the procedures described in APHA (1995). In addition, independent rainfall rates for areas near each studied zone were provided by LABESA (Laboratory of Semi-Arid Ecology).

Zooplankton was collected using a $25 \mathrm{~cm}$ mouth diameter plankton net with $60 \mu \mathrm{m}$ of mesh size by filtering $70 \mathrm{~L}$ of water at the subsurface $(<100 \mathrm{~cm}$ depth) during horizontal trawls at each sampling site, totalling $140 \mathrm{~L}$ of filtered water per zone. We estimated the distance necessary to filter the intended volume following (Equation 1):

$\mathrm{V}_{\mathrm{f}}=\pi \cdot \mathrm{r}^{2} \cdot \mathrm{d}$

where: $\mathrm{V}_{\mathrm{f}}$ is the volume intended (i.e. $70 \mathrm{~L}$ ), $\mathrm{r}$ is the radius of net mouth aperture (i.e. $0.125 \mathrm{~m}$ ) and $\mathrm{d}$ is the trawled distance necessary to filter $70 \mathrm{~L}$ (Bicudo, CEM. and Bicudo, DC., 2007). The results suggested that a distance of $\sim 57 \mathrm{~m}$ was necessary to filter $70 \mathrm{~L}$ of water and plankton trawls were conducted that way within each permanent sampling site using a GPS.

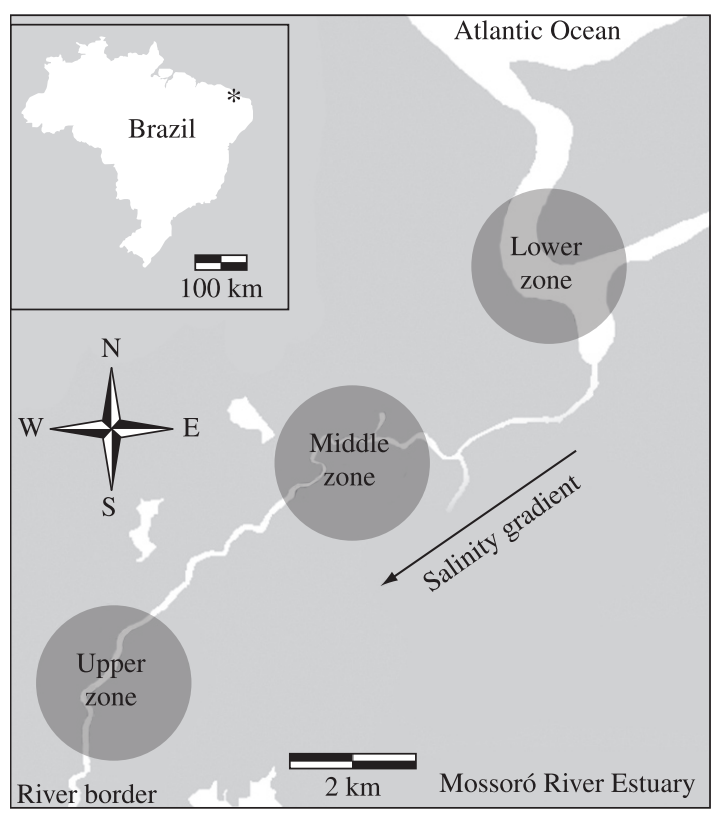

Figure 1. Location and map of the Mossoró River Estuary with the three studied zones highlighted. 
The collected individuals were preserved in 5\% formaldehyde saturated with sugar (Haney and Hall, 1973), and three aliquots ( $1 \mathrm{~mL}$ volume each) were taken from each sample (between 80 and $140 \mathrm{~mL}$ ). Zooplankton counting was made for each aliquot separately by using a Sedgwick-Rafter counting chamber. If an aliquot had less than 100 individuals another one was examined and the results combined. The mean number of individuals of the three aliquots was used as the representative of each sample. Species richness and abundance of individuals are expressed as number of species per litre of filtered water (species. $\mathrm{L}^{-1}$ ) and number of individuals per litre of filtered water (ind. $\mathrm{L}^{-1}$ ), respectively.

\subsection{Data analysis}

We tested normality with the Shapiro-Wilk test and square-root transformed the data. Since data of some species departed from normality even after transformation, particularly due to low observed numbers, we excluded them from the analyses (see Results), but their values contributed to total species richness and abundance. We performed factorial MANOVA (orthogonal sum of squares) to test whether variations in the response variables (environmental variables and species) could be accounted for by a function of two fixed factors, namely, the estuarine zones and seasonality. We chose Pillai trace (V) as the test statistic given it is the most robust to violations of homogeneity of variances (Wilkinson et al., 1996). Tukey's HSD test was performed as a post-hoc test among means. In case of significance we used separate one-way ANOVAs for each dependent variable to detect which mostly contributed to the observed variations.

Stepwise multiple regression analysis was performed to test which, and to what degree, the evaluated environmental variables (predictors) contributed to the observed variances of rotifer species distribution (entered as the dependent variables). Multicolinearity tests accomplished between the independent variables indicated that the data was non-linear (Sokal and Rohlf, 1995).

Finally, to test the particular influences of salinity and rainfall, we performed a fixed factor factorial ANCOVA (orthogonal sum of squares) to test the effects of the estuarine zones, seasonality and their interaction term on rotifer richness and abundance. We performed two analyses for each dependent variable (richness and abundance) with two co-variates used, namely, salinity and rainfall. Tukey's HSD test was performed as a post-hoc test among means. All abovementioned analyses were performed using STATISTICA software.

\section{Results}

Highly significant spatial and seasonal differences were observed for the evaluated environmental variables (Table 1a; see Figure 2). The interaction term was also highly significant, suggesting that spatial differences were season-dependent. Spatial differences were mostly the result of the upper zone (UZ) showing significantly different values than the lower (LZ) and middle (MZ) zones for most evaluated months (Tukey's HSD test; $\mathrm{p}<0.05$ ). Further, salinity, temperature, transparency, Chrorophyll- $a$, $\mathrm{pH}$ and pheophytin contributed the most to the observed spatial variance (ANOVA; $p<0.01$ ). Season variations were more remarkable in the UZ and MZ (Tukey's HSD test; $\mathrm{p}<0.05$ ), particularly due to fluctuations in the values of rainfall, salinity, $\mathrm{O}_{2}$, temperature, $\mathrm{NH}_{3}$ and TP (ANOVA; $\mathrm{p}<0.01$ ) (Figure 2). The LZ showed somewhat small seasonal variation, particularly due to fluctuations in the values of rainfall, transparency and temperature.

A total of 49,441 individuals from 16 rotifer species were collected. At the LZ, 1,010 individuals (2.06\% of total abundance) from 7 species (Brachionus angularis (Gosse), Brachionus calyciflorus Pallas, Brachionus leydigi (Rousselet), Brachionus plicatilis Müller, Brachionus urceolaris (Müller), Epiphanes macrourus (Barrois and Daday) and Filinia longiseta (Ehrenberg)) were collected, whereas 8,976 individuals ( $18.31 \%$ of total abundance) from 12 species (the aforementioned plus Anuraeopsis fissa (Gosse), Brachionus caudatus Barrois and Daday, Hexarthra mira (Hudson), Keratella tropica (Apstein) and Keratella valga (Ehrenberg)) were collected at the $\mathrm{MZ}$ and 39,044 individuals (79.63\% of total abundance) from 16 species (all of the aforementioned plus Brachionus falcatus Zacharias, Brachionus patulus (Müller), Filinia opoliensis (Zacharias) and Polyarthra vulgaris (Ehrenberg)) were collected at the UZ. Due to rarity, A. fissa, B. caudatus, $B$. falcatus, B. patulus, $F$. longiseta, $F$. opoliensis and $P$. vulgaris were excluded from the analyses.

Abundances of the analysed species varied with estuarine zones and seasonality, and their interaction term was also highly significant (Table 1b). Spatial differences were mostly the results of an upstream increasing pattern in all months (Tukey's HSD test; $\mathrm{p}<0.05$ ), mostly due to variations in the abundances of B. leydigi, B. plicatilis, $B$. urceolaris, E. macrourus and $K$. tropica (ANOVA; $\mathrm{p}<0.05$ ). Seasonally, variations were highly remarkable at the UZ (Tukey's HSD test; $\mathrm{p}<0.01$ ), with all species showing higher abundances during the rainy months

Table 1. Results of factorial MANOVA on the effects of three estuarine zones and seasonality of a) environmental variables and b) rotifer species from an annual sampling effort at the Mossoró River Estuary. Refer to text for post-hoc results.

\begin{tabular}{|c|c|c|c|c|c|}
\hline Source & $\begin{array}{c}\text { Pillai's } \\
\text { trace }\end{array}$ & $\mathbf{F}$ & $\begin{array}{c}\text { Effect } \\
\text { df }\end{array}$ & $\begin{array}{c}\text { Error } \\
\text { df }\end{array}$ & $\mathbf{p}$ \\
\hline \multicolumn{6}{|l|}{ a) } \\
\hline Zones & 1.54 & 7.2 & 24 & 52 & $<0.001$ \\
\hline Months & 6.05 & 3.6 & 132 & 385 & $<0.001$ \\
\hline $\mathrm{Z} \times \mathrm{M}$ & 6.16 & 1.7 & 264 & 432 & $<0.001$ \\
\hline \multicolumn{6}{|l|}{ b) } \\
\hline Zones & 1.41 & 7.73 & 18 & 58 & $<0.001$ \\
\hline Months & 4.56 & 3.36 & 99 & 324 & $<0.001$ \\
\hline $\mathrm{Z} \times \mathrm{M}$ & 5.56 & 2.64 & 198 & 324 & $<0.001$ \\
\hline
\end{tabular}



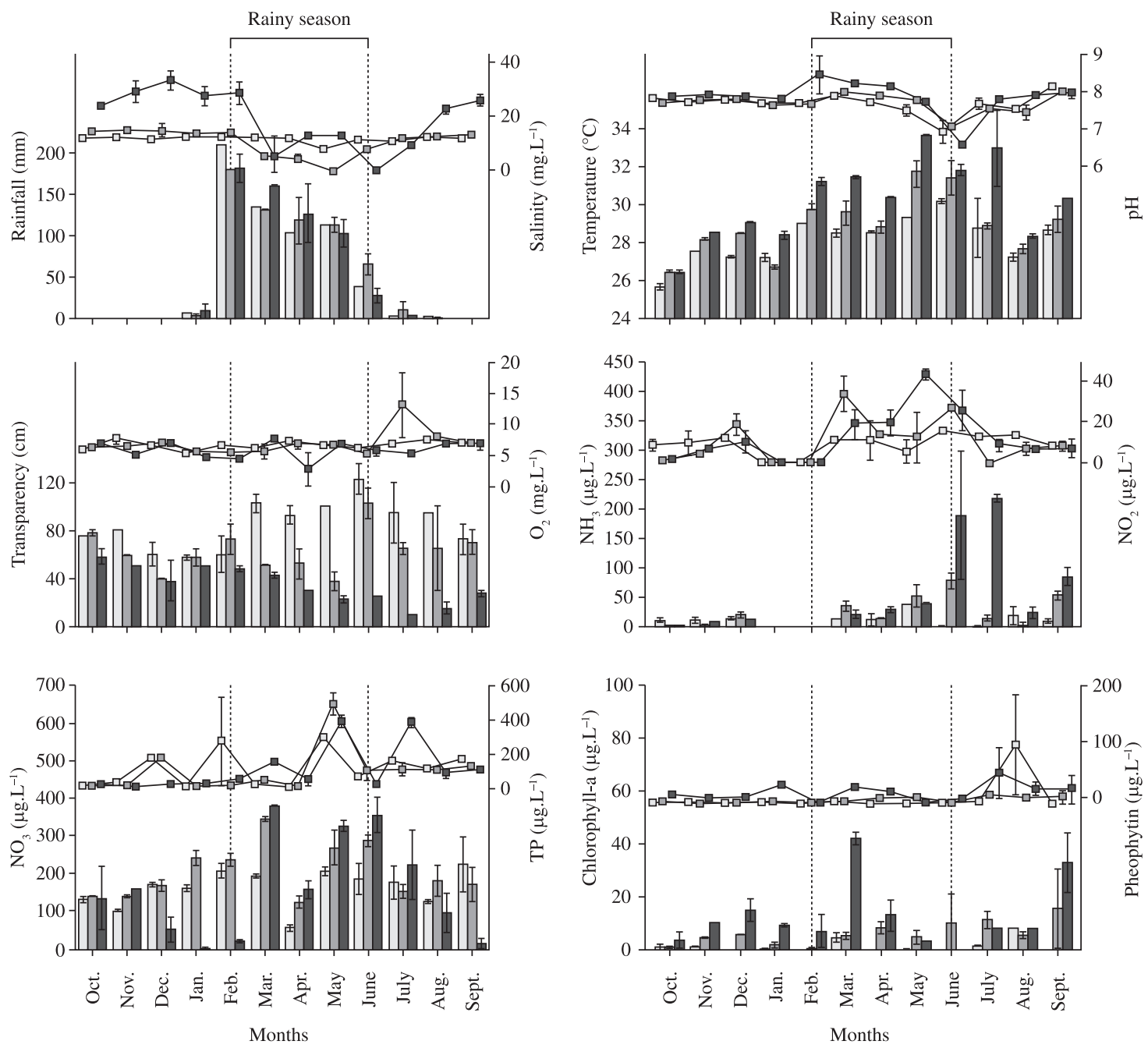

口 Lower $\square$ Middle $\square$ Upper

Figure 2. Mean values $( \pm S E)$ of environmental variables sampled during an annual effort at the lower, middle and upper estuarine zones at the Mossoró River Estuary.

(ANOVA; $\mathrm{p}<0.001)$. However, seasonal variations were also observed at the $\mathrm{MZ}$ and, albeit to a less extent, at the LZ.

Results of multiple regression analyses revealed that, with few exceptions (i.e. K. tropica and K. valga), environmental variables were somewhat poor predictors of rotifer abundances (Table 2). Overall, temperature and $\mathrm{NH}_{3}$ had a positive influence on species abundances, whereas transparency and $\mathrm{NO}_{2}$ had a negative effect.

In the ANCOVA, both richness and abundance varied with estuarine zone and seasonality, and their interaction terms were also significant (Table 3; see Figure 3). Richness and abundance were higher at the UZ and during the rainy months (Tukey's HSD test; $\mathrm{p}<0.001$ ). The effect of salinity as a co-variate was only significant for rotifer abundance, but the effect of rainfall as a co-variate was significant for both richness and abundance.

\section{Discussion}

The Mossoró River Estuary was characterised by a predominance of oligohaline and polyhaline salinity regimes, with a noticeable upstream increasing salinity gradient. Typical estuaries tend to show the opposite pattern with downstream salinity gradients frequently observed (Barletta-Bergan et al., 2002; Magalhães et al., 2006). Due to the well-known negative influence of salinity on many zooplankton species (e.g. Hammer, 1993; Lansac-Tôha and Lima, 1993; Keller and Conlin, 1994; Williams, 1998; Epifanio and Garvine, 2001; Herbst, 2001; Ara, 2002; Derry et al., 2003; Toumi et al., 2005), one would expect to find lower rotifer richness and abundance at zones with higher salinity, but the opposite pattern was observed for the present study, salinity, richness and abundance showing higher values in the UZ. However, seasonally, salinity 
Table 2. Results of stepwise multiple regression analyses for nine rotifer species and environmental predictors from an annual sampling effort at three estuarine zones at the Mossoró River Estuary. Rainfall, pH, total phosphorous and pheophytin did not contribute to the observed variances in rotifer abundances and were not included.

\begin{tabular}{|c|c|c|c|c|c|c|c|c|c|c|}
\hline \multirow[t]{2}{*}{ Species } & \multicolumn{2}{|c|}{ Regression } & \multicolumn{8}{|c|}{ Predictors (contribution to total $\mathbf{R}^{2}$ ) } \\
\hline & $\mathbf{F}$ & $\mathbf{R}^{2}$ & $\mathbf{S}$ & $\mathbf{T}$ & WT & $\mathrm{O}_{2}$ & $\mathrm{NH}_{3}$ & $\mathrm{NO}_{2}$ & $\mathrm{NO}_{3}$ & Ch- $a$ \\
\hline B. cal ** & 4.18 & 0.46 & & & -0.27 & & 0.37 & & & \\
\hline B. ley NS & 0.92 & 0.16 & & & & & & & & \\
\hline B. urc NS & 2.75 & 0.36 & & & & & & & & \\
\hline B. pli ** & 4.21 & 0.46 & & & & & & & -0.35 & \\
\hline B. ang $* *$ & 5.06 & 0.51 & & & & & & -0.31 & 0.32 & \\
\hline E. $\operatorname{mac} *$ & 2.63 & 0.35 & 0.40 & & & & & & & \\
\hline H. mir $* *$ & 5.01 & 0.50 & & 0.47 & -0.28 & 0.25 & & -0.44 & & \\
\hline K. tro $* *$ & 7.35 & 0.60 & & 0.55 & -0.29 & & & & & \\
\hline K. val $* *$ & 5.76 & 0.54 & & 0.37 & -0.45 & & 0.30 & -0.30 & & -0.27 \\
\hline
\end{tabular}

B. cal: Brachionus calyciflorus; B. ley: Brachionus leydigi; B. urc: Brachionus urceolaris; B. pli: Brachionus plicatilis; B. ang: Brachionus angularis; E. mac: Epiphanes macrourus; H. mir: Hexarthra mira; K. tro: Keratella tropica; K. val: Keratella valga; $*$ : $<0.01 ; * *: \mathrm{p}<0.001 ;$ NS: non-significant

and rotifer numbers showed major contrasting patterns which were the most critical structuring forces on rotifer distribution in the present study.

The most abundant species in the study were Brachionus plicatilis, Brachionus calyciflorus, Epiphanes macrourus and Brachionus urceolaris, which accounted together for $74 \%$ of all collected individuals. Also, species richness and abundance increased upstream from the LZ to the UZ. In fact, $80 \%$ of all individuals were collected in the UZ and only 2 and $18 \%$ were found in the LZ and MZ, respectively. Most of the rotifer species collected at the Mossoró River Estuary were typical freshwater dwellers (Stemberg, 1979; Fontaneto et al., 2006) and a prominent negative seasonal influence of salinity on these species was observed. Negative influence of salinity on rotifer composition has been detected elsewhere (e.g. Wooldridge and Callahan, 2000; Fontaneto et al., 2006; Zakaria et al., 2007). Epifanio and Garvine (2001) also pointed out the physiological constraints of salinity on the larval stages of freshwater dwellers. On the other hand, many authors have detected a clear positive influence of freshwater on different zooplankton communities (Park and Marshall, 2000; Epifanio and Garvine, 2001; Kimmel et al., 2006).

The three estuarine zones evaluated and chosen based on their proximity to the ocean or the river border, showed marked environmental differences. Thus, species dwelling within these zones were clearly under different influences. Particularly, salinity and freshwater discharge played major roles in determining rotifer distribution in the estuary and the other variables seemed to show very little importance.

Salt concentration in the UZ showed values nearly two times higher when compared to each of the other zones, and although most of the collected individuals throughout the study were observed in this zone, $85 \%$ were exclusively collected during the rainy months. Also, in the LZ and MZ, $89 \%$ and $83 \%$ of all individuals, respectively, were collected during the rainy season. Therefore, very low abundances were detected during the dry seasons in all zones.

These observations clearly pinpoint the highly positive influence of freshwater discharge on species of the studied area. Rainfall rates were similar in all zones, but seasonal salinity fluctuations were higher near the river border, suggesting that proximity to the river was a major determinant of rotifer distribution. Therefore, river discharge during the rainy season likely displaced the individuals from the river towards the estuary. Although this was probably the result of a strictly passive dislocation, individuals were alive during our samplings, suggesting tolerance to the observed hydrodynamics at the upper reach of the estuary. Similar patterns of species dislocation have been detected before (Kimmel et al., 2006; Silva et al., 2009). In fact, due to higher freshwater input during the rainy months, salt concentration in the UZ and MZ decreased significantly to approximately half of the value observed during the dry season. Previous studies have also observed significant decreases in salinity concentrations due to precipitation rates during the rainy season (e.g. Barletta, 1999; Magalhães et al., 2006).

Seasonal salinity fluctuations were not observed in the LZ. This zone permanently receives saline water and, despite similar seasonal rainfall rates in all zones, salt concentrations were not altered during the rainy months in the LZ. This is likely the result of the proximity of this zone to the ocean and the higher tidal influence. Therefore, a somewhat equivalent freshwater and saltwater input at this zone created permanent brackish regimes yearlong. However, aside from this observation, seasonality was also a major influence on rotifer species structure in this zone, since most individuals were collected during the rainy season. However, B. plicatilis, a known brackish-tolerant species (Theilacker and McMaster, 1971; Epp and Winston, 1977; Thomaz et al., 2004; Fontaneto et al., 2006), accounted for $70 \%$ of the individuals found in this zone in both dry and 
Table 3. Results of factorial ANCOVA on the effects of three estuarine zones and seasonality using salinity and rainfall as co-variates on rotifer richness and abundance from an annual sampling effort at the Mossoró River Estuary. Refer to text for post-hoc results.

\begin{tabular}{llrrl}
\hline \multirow{4}{*}{ Richness } & Source & df & F & p \\
& Zones & 2 & 12.73 & $<0.001$ \\
& Months & 11 & 19.25 & $<0.001$ \\
& Zx M & 22 & 2.80 & $<0.01$ \\
& Salinity & 1 & 0.56 & NS \\
Abundance & Zones & 2 & 11.39 & $<0.001$ \\
& Months & 11 & 23.90 & $<0.001$ \\
& Zx M & 22 & 18.55 & $<0.001$ \\
& Salinity & 1 & 5.35 & $<0.05$ \\
Richness & Zones & 2 & 43.24 & $<0.001$ \\
& Months & 11 & 17.03 & $<0.001$ \\
& Zx M & 22 & 3.55 & $<0.001$ \\
& Rainfall & 1 & 5.80 & $<0.05$ \\
Abundance & Zones & 2 & 93.58 & $<0.001$ \\
& Months & 11 & 20.83 & $<0.001$ \\
& Zx M & 22 & 21.37 & $<0.001$ \\
& Rainfall & 1 & 10.75 & $<0.01$ \\
\hline
\end{tabular}

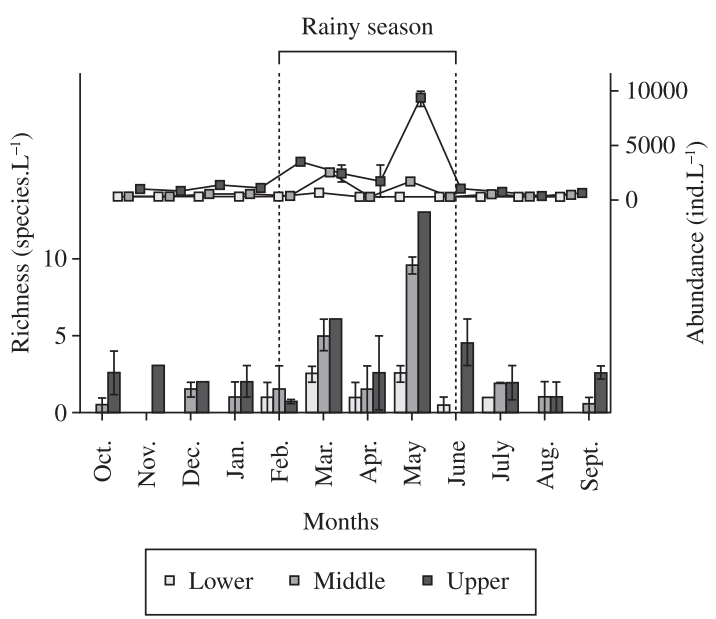

Figure 3. Mean values $( \pm S E)$ of rotifer richness and abundance sampled during an annual effort at the lower, middle and upper estuarine zones at the Mossoró River Estuary.

rainy months. In the $\mathrm{MZ}$ and $\mathrm{UZ}$, this species accounted, respectively, for $44 \%$ and $23 \%$ of the total abundance. Therefore, a decreasing upstream pattern in the relative proportion of this species was clearly observed. This supports the idea that, despite higher salinity values in the UZ, due to high influence of the river proximity, harsher conditions were observed at the LZ and MZ, where the stenohaline $B$. plicatlis dominated.

The present study highlights the negative influence of salinity and the positive influence of freshwater discharge due to river proximity as a major structuring force of rotifer distribution. Although salt concentration was higher at the upper zone where richness and abundance were also higher, species composition was negatively affected by salinity on a seasonal basis. These observations suggest that the horizontal salinity gradient and their seasonal fluctuations were highly dependent upon each other, and this relationship was consistent with the highly significant interaction term observed within all analyses of variances. Also, for an estuary located in an area subject to high evaporation rates yearlong, the study pinpoints the importance of seasonality and river proximity as major determinants of rotifer species in semiarid estuarine environments.

Acknowledgements - The authors are grateful to the personnel of LABESA (Laboratório de Ecologia do Semi-Árido) and LEAq (Laboratório de Ecologia Aquática) for field assistance, two anonymous referees and CAPES and CNPq for the financial support.

\section{References}

American Public Health Association - APHA, 1995. Standard methods for the examination of water and waste water. Washington. $1524 \mathrm{p}$.

ARA, K., 2002. Temporal variability and production of Temora turbinata (Copepoda: Calanoida) in the Cananéia Lagoon estuarine system, São Paulo, Brazil. Scientia Marina, vol. 66, no. 4, p. 399-406.

BARLETTA, M., 1999. Seasonal changes of density, biomass and species composition of fishes in different habitats of the Caeté estuary (North Brazilian coast-east Amazon). Germany: Bremen University. 115 p. [Tese de Doutorado]

BARLETTA-BERGAN, A., BARLETTA, M. and SAINT-PAUL, U., 2002. Structure and seasonal dynamics of larval fish in the Caeté river estuary in North Brazil. Estuarine, Coastal and Shelf Science, vol. 54, no. 2, p. 193-206.

BICUDO, CEM. and BICUDO, DC., 2007. Amostragem em limnologia. São Carlos: Rima. 351 p.

DERRY, AM., PREPAS, EE. and HEBERT, PDN., 2003. A comparison of zooplankton communities in saline lakewater with variable anion composition. Hydrobiologia, vol. 505, no. 1, p. $199-215$

EPIFANIO, CE. and GARVINE, RW., 2001. Larval transport on the Atlantic Continental Shelf of North America: a review. Estuarine, Coastal and Shelf Science, vol. 52, no. 1, p. 51-77.

EPP, RW. and WINSTON, PW., 1977. Osmotic regulation in the brackish-water rotifer Brachionus plicatilis (Mullers). Journal of Experimental Biology, vol. 68, p. 151-156.

FONTANETO, D., SMET, WH. and RICCI, C., 2006. Rotifers in saltwater environments, re-evaluation of an inconspicuous taxon. Journal of the Marine Biological Association of the United Kingdom, vol. 86, no. 4, p. 623-656.

HAMMER, UT., 1986. Saline ecosystems of the world. Dordrecht: Junk Publishers. $632 \mathrm{p}$.

HAMMER, UT., 1993. Zooplankton distribution and abundance in saline lakes of Alberta and Saskatchewan, Canada. International Journal of Salt Lake Research, vol. 2, no. 2, p. 111-132. 
HANEY, JF. and HALL, DJ., 1973. Sugar-coated Daphnia: a preservation technique for Cladocera. Limnology and Oceanography, vol. 18 , no. 3, p. 331-333.

HERBST, DB., 2001. Gradients of salinity stress, environmental stability and water chemistry as a templet for defining habitat types and physiological strategies in inland salt waters. Hydrobiologia, vol. 466, no.1, p. 209-219.

KELLER, W. and CONLIN, M., 1994. Crustacean zooplankton communities and lake morphometry in Precambrian Shield lakes. Canadian Journal of Fisheries and Aquatic Sciences, vol. 51, no. 11 , p. 2424-2434.

KIMMEL, DG., ROMAN, MR. and ZHANG, X., 2006. Spatial and temporal variability in factors affecting mesozooplankton dynamics in Chesapeake Bay: evidence from biomass size spectra. Limnology and Oceanography, vol. 51, no. 1, p. 131-141.

LANSAC-TÔHA, FA. and LIMA, AF., 1993. Ecologia do zooplâncton do estuário do rio Una do Prelado (São Paulo, Brasil). Acta Limnologica Brasiliensia, vol. 6, no. 1, p. 82-96.

LOPES, RM., 1994. Zooplankton distribution in the Guarau River Estuary (South-eastern Brazil). Estuarine, Coastal and Shelf Science, vol. 39, no. 1, p. 287-302.

MACKERETH, FJH., HERON, J. and TALLING, JF., 1978. Water analysis: some revised methods for limnologists. Freshwater Biological Association Scientific Publication, vol. 36, p. 1-121.

MAGALHÃES, A., COSTA, RM., LIANG, TH., PEREIRA, LCC. and RIBEIRO, MJS., 2006. Spatial and temporal distribution in density and biomass of two Pseudodiaptomus species (Copepoda: Calanoida) in the Caeté River Estuary (Amazon region - North of Brazil). Brazilian Journal of Biology, vol. 66, no. 2a, p. 421-430.

MEDEIROS, GS., 1983. Variação sazonal e diurnal do zooplâncton no estuário Potengi, Natal/RN (com especial referência aos Copepoda - Crustacea). Paraná: Universidade Federal do Paraná. 99 p. [Dissertação de Mestrado]

MIRACLE, MR. and SERRA, M., 1989. Salinity and temperature influence in rotifer life history characteristics. Hydrobiologia, vol. 186-187, no. 1, p. 81-102.

NEUMANN-LEITÃO, S., 1994. Resenha literária sobre o zooplâncton estuarino no Brasil. Trabalhos Oceanográficos, vol. 23 , no. 1 , p. $25-53$.

ONWUDINJO, CC. and EGBORGE, ABM., 1994. Rotifers of Benin River, Nigeria. Hydrobiologia, vol. 272, no. 1, p. 87-94.

PARK, GS. and MARSHALL, HG., 2000. Estuarine relationships between zooplankton community structure and trophic gradients. Journal of Plankton Research, vol. 22, no. 1, p. 121-135.
REMANE, A. and SCHLIEPER, C., 1971. The biology of brackish waters. New York: Wiley Interscience. $372 \mathrm{p}$.

RODIER, JL., 1975. Analyse de l'eau: eaux naturelles, eaux residuals, eaux de mer. Paris: Dunod. 692 p.

SHIEL, RJ., COSTELLOE, JF., REID, JRW., HUDSON, P. and POWLING, J., 2006. Zooplankton diversity and assemblages in arid zone rivers of the Lake Erye Basin, Australia. Marine and Freshwater Research, vol. 57, no. 1, p. 49-60.

SILVA, AM., BARBOSA, JEL., MEDEIROS, PR., ROCHA, RM., LUCENA FILHO, MA. and SILVA, DF., 2009. Zooplankton (Cladocera and Rotifera) variations along a horizontal salinity gradient and during two seasons (dry and rainy) in a tropical inverse estuary. Pan-American Journal of Aquatic Sciences, vol. 4, p. 226-237.

SOKAL, RR. and ROHLF, FJ., 1995. Biometry: the principles and practice of statistics in biological research. New York: W. H. Freeman \& Company. 887 p.

STEMBERG, R., 1979. A guide to Rotifers. Cincinnati: U.S. Environmental Protection Agency. 185 p.

THEILACKER, GH. and MCMASTER, MF., 1971. Mass culture of the rotifer Brachionus plicatilis and its evaluation as a food for larval anchovies. International Journal on Life in Oceans and Coastal Waters, vol. 10, no. 2, p. 183-188.

THOMAZ, LA., OSHIRO, LMY., BAMBOZZI, AC., SEIXAS FILHO, JT. and ROSADAS, LAS., 2004. Substituição de Artemia sp. pelo rotífero Brachionus plicatilis na larvicultura do camarãod'água-doce (Macrobrachium rosembergii De Man, 1879). Revista Brasileira de Zootecnia, vol. 33, no. 6, p. 1928-1933.

TOUMI, N., AYADI, H., ABID, O., CARRIAS, JF., SIRNENGANDO, S., BOUKHRIS, M. and BOUAIN, A., 2005. Zooplankton distribution in four ponds of different salinity: a seasonal study in the solar salterns of Sfax (Tunisia). Hydrobiologia, vol. 534, p. 1-9.

WILLIAMS, WD., 1998. Salinity as a determinant of the structure of biological communities in salt lakes. Hydrobiologia, vol. 381, no. 6 , p. 191-201.

WILKINSON, L., BLANK, G. and GRUBER, C., 1996. Desktop data analysis with SYSTAT. Englewood Cliffs: Prentice Hall. $718 \mathrm{p}$.

WOOLDRIDGE, TH. and CALLAHAN, R., 2000. The effects of a single freshwater release into the Kromme Estuary. 3: Estuarine zooplankton response. Water $S A$, vol. 26, no. 3, p. 311-318.

ZAKARIA, HY., RADWAN, AA. and SAID, MA., 2007. Influence of salinity on zooplankton community in El-Mex Bay, Alexandria, Egypt. Egyptian Journal of Aquatic Research, vol. 33 , no. 3, p. 52-67. 
